\title{
WYMAN-GORDON AND THE EXCELSIOR RULE
}

Whether administrative agencies should formulate substantive policies by adjudication or rulemaking ${ }^{1}$ has been a source of considerable controversy among legal scholars, the courts, and Congress. Some academicians have urged that agencies increase their use of rulemaking. ${ }^{2}$ Others have argued that the distinction between rulemaking and adjudication is unclear, and that the significance of the choice between the two processes has been exaggerated. ${ }^{3}$

The settled judicial treatment of the issue leaves to an agency the choice of how to proceed. In SEC v. Chenery Corp., ${ }^{4}$ the Supreme Court observed that since agencies must retain power to deal with specialized problems on a case-by-case basis if the administrative process is to be effective, "an administrative agency must be equipped to act either by general rule or by individual order." 's Therefore, the Court

1 As used in this Comment, the terms "adjudication" and "rulemaking" refer to the processes governed by the specific procedures set forth in $\$ \$ 4$ and 5 of the Administrative Procedure Act, 5 U.S.C. \$§ 553, 554 (Supp. III, 1968), replacing 5 U.S.C. $\$ \$ 1003,1004$ (1964). The definitions provided by the Act are not particularly helpful :

§51. Definitions

(4) "rule" means the whole or a part of an agency statement of general or particular applicability and future effect designed to implement, interpret, or prescribe law or policy or describing the organization, procedure, or practice requirements of an agency and includes the approval or prescription for the future of rates, wages, corporate or financial structures or reorganizations thereof, prices, facilities, appliances, services or allowances therefor or of valuations, costs, or accounting, or practices bearing on any of the foregoing;

(5) "rule making" means agency process for formulating, amending, or repealing a rule;

(6) "order" means the whole or a part of a final disposition, whether affirmative, negative, injunctive, or declaratory in form, of an agency in a matter other than rule making but including licensing;

(7) "adjudication" means agency process for the formulation of an order;

2 See, e.g., K. Davis, Administrative Law TrEatise $\$ 6.13$ (1967 Pocket Part) ; Berger, Retroactive Administrative Decisions, 115 U. PA. L. REv. 371, 374-75 (1967); Peck, The Atrophied Rule-Making Powers of the National Labor Relations Board, 70 YALE L.J. 729 (1961); Peck, A Critique of the National Labor Relations Board's Performance in Policy Formulation: Adjudication and Rule-Making, 117 U. PA. L. REv. 254 (1968) ; Shapiro, The Choice of Rulemaking or Adjudication in the Development of Administrative Policy, 78 HARv. L. Rev. 921, 972 (1965).

3 See L. Jaffe \& N. Nathanson, Administrative Law 23-24 (3d ed. 1968); Shapiro, supra note 2, at 926, 972.

4332 U.S. 194 (1947).

5 Id. at 202. The Court continued:

To insist upon one form of action to the exclusion of the other is to exalt form over necessity.

In other words, problems may arise in a case which the administrative agency could not reasonably foresee, problems which must be solved despite the absence of a relevant general rule. Or the agency may not have had 
held, "the choice made between proceeding by general rule or by individual, ad hoc litigation is one that lies primarily in the informed discretion of the administrative agency." 6

Although the Administrative Procedure Act ${ }^{7}$ (hereafter the APA) prescribes specific procedures that must be followed once the choice of rulemaking or adjudication has been made, it fails to indicate which process should be used in a given situation. ${ }^{8}$ Courts struggling to divine legislative intent on this issue, while sometimes favoring increased use of rulemaking, ${ }^{9}$ have nevertheless followed the Chenery view that the choice remains discretionary with the agency. Judge Henry Friendly's statement in NLRB v. A.P.W. Products Co. is typical:

But our question is not of wisdom but of authority. Congress cannot have been blind to the fact that the adjudicative process of the agencies, like that of the courts, gives birth to "rules," which may apply for the past, for the future, or, more generally, for both. . . . [W] hether to use one method of law making or the other is a question of judgment, not of power. ${ }^{10}$

In the recent case of Wyman-Gordon Co. $v . N L R B,{ }^{11}$ however, the Court of Appeals for the First Circuit denied enforcement of an order of the regional director which he had issued in accordance with a "rule" established by the NLRB in Excelsior Underwear, Inc. ${ }^{12}$ Enforcement was denied only ${ }^{13}$ on the grounds (1) that in Excelsior, the Board had engaged in rulemaking, and (2) that as a consequence the resultant rule was promulgated "in disregard of the notice and publication requirements of the Administrative Procedure Act," requirements which apply to rulemaking but not to adjudication. ${ }^{14}$ The court

sufficient experience with a particular problem to warrant rigidifying its tentative judgment into a hard and fast rule. Or the problem may be so specialized and varying in nature as to be impossible of capture within the boundaries of a general rule. In those situations, the agency must retain power to deal with the problems on a case-to-case basis if the administrative process is to be effective. Id. at 202-03. (1965).

6 Id. at 203. See also California v. Lo-Vaca Gathering Co., 379 U.S. 366, 371

7 U.S.C. $\$ \$ 551-59$ (Supp. III, 1968), replacing 5 U.S.C. \$\$1001-11 (1964).

8 See 5 U.S.C. $\$ \S 553,554$ (Supp. III, 1968). The definitions in 5 U.S.C. $\S 551$ (Supp. III, 1968), reproduced in note 1 supra, provide little guidance.

9 See, e.g., NLRB v. A.P.W. Prods. Co., 316 F.2d 899, 905 (2d Cir. 1963).

$10 \mathrm{Id}$.

11397 F.2d 394 (1st Cir.), cert. granted, 393 U.S. 939 (1968).

12156 N.L.R.B. 1236 (1966).

13 The court did not dispute that such a "rule" could be adopted through adjudication. 397 F.2d at 396 .

14 Id. at 396-98. See 5 U.S.C. $\$ 553$ (Supp. III, 1968), which provides the procedures that must be followed in rulemaking. 
reasoned that the Board had not been engaged in adjudication in Excelsior because the rule it established there was applied only prospectively. ${ }^{15}$ Since the Board in Excelsior had not chosen to engage in adjudication but rather to engage in rulemaking without complying with the APA procedural requirements, Chenery was held to be inapplicable. ${ }^{16}$ Chenery merely decided the agency had discretion in its choice of processes. But here, the court held, the Board had made its choice-it was exercising its rulemaking power.

\section{THE Excelsior RULE}

In the Excelsior case, an election by secret ballot had been conducted by the regional director pursuant to a stipulation for certification upon consent election. The union had requested that the employer supply it with the names and addresses of the employees eligible to vote. The employer refused, the election was held, and the union lost. The union filed objections with the regional director alleging that the election should be set aside because the employer had refused to supply the list of names and addresses. After investigation, the regional director issued a report recommending that the objections be overruled and the election results certified. Pursuant to the Board's regulations under section 9 of the National Labor Relations Act, the union filed with the Board exceptions to the regional director's report. ${ }^{17}$ The Board determined that the employer's denial of the union's request for the names and addresses "presented a question of substantial importance in the administration of the National Labor Relations Act" and ordered that oral argument be heard before the Board. ${ }^{18}$

Prior to the hearing in Excelsior, the Board invited interested parties to submit amicus briefs. During the proceeding it heard argument concerning the need for and the appropriate scope and implementation of a rule that would require employers to supply voter lists to the union. ${ }^{19}$ The Board gave extensive discussion in its opinion of the pros and cons of the proposed policy ${ }^{20}$ and concluded that " $[\mathrm{t}]$ he arguments against imposing a requirement of disclosure are of little force especially when weighed against the benefits resulting therefrom." 21

15 Id. at 397.

$10 \mathrm{Id}$.

17 See 29 C.F.R. $\$ 101.21$ (d) (1968).

18156 N.I.R.B. 1236, 1238 (1966).

Ordinarily, the regional director's certification is final; his decisions are reviewed by the Board only where there are compelling reasons for such review as, for example, when a substantial question of law or policy is involved. 29 C.F.R. $\$ 101.21$ (d) (1968). See A. Cox \& D. Bor, Cases and Materials on Labor Law 366-67 (6th ed. 1965).

$10 \mathrm{Id}$. at 1238 .

20 Id. at 1240-45.

21 Id. at 1243. 
Accordingly, the Board stated that it would invalidate any election where the employer had not submitted a list of the names and addresses of all eligible voters to the Board's regional director within seven days after the election had been ordered, or after a consent-election agreement had been approved. ${ }^{22}$ Apparently out of considerations of fairness, ${ }^{23}$ the Board refused to set aside the Excelsior election:

However, the rule we have here announced is to be applied prospectively only. It will not apply in the instant cases but only in those elections that are directed, or consented to, subsequent to 30 days from the date of this Decision. We impose this brief period of delay to insure that all parties to forthcoming representation elections are fully aware of their rights and obligations as here stated. ${ }^{24}$

There has been some dispute concerning whether the Board may set aside an election for failure to supply an "Excelsior list," but most authorities have held such action to be a valid exercise of the Board's power to control the conduct of elections. ${ }^{25}$ However, the sanction of setting aside elections for failure to comply with the list requirement proved to be inadequate: as long as the employer kept winning the elections, he could defer unionization indefinitely. The Board has accordingly sought to close this gap by forcing compliance through the courts. Judicial enforcement has been sought - and received ${ }^{26}$-on two theories: (1) that the lists can be subpoenaed as evidence under section 11 of the National Labor Relations Act, ${ }^{27}$ and (2) that an injunction can be obtained from a federal district court under section 1337 of the Judicial Code. ${ }^{28}$ It has been argued that to allow the Board to enforce an "election policy" in the district courts, regardless of whether violation of that policy would amount to an unfair labor practice or not, is to allow the Board to circumvent the elaborate procedures for review of Board orders set up in the National Labor Relations Act. ${ }^{29}$ The court in Wyman-Gordon indicated that it had no objections to such a procedure and was disposed to affirm the district court's enforcement of the Board's subpoena ${ }^{30}$ but felt that the

22 Id. at 1239-40.

23 Id. at 1240 n.5, 1246.

$24 \mathrm{Id}$. at $1240 \mathrm{n} .5$.

25 See Comment, Enforcement of the Excelsior Rule in the District Courts, 116 U. PA. L. REv. 1434, 1435, 1442-44 (1968).

${ }^{26}$ See, e.g., Howell Refining Co. v. NLRB, 400 F.2d 213 (5th Cir. 1968) ; NLRB v. Rohlen, 385 F.2d 52 (7th Cir. 1967) ; NLRB v. Hanes Hosiery Div., 384 F.2d 188 (4th Cir. 1967), cert. denied, 390 U.S. 950 (1968).

$2 \tau 29$ U.S.C. $\$ 161$ (1964).

2828 U.S.C. $\$ 1337$ (1964).

29 See Comment, supra note 25.

30397 F.2d 394, 396-97 (1st Cir. 1968). 
substantive policy the Board sought to enforce was "improperly promulgated" and therefore inappropriate for judicial enforcement. The procedural argument accepted by the First Circuit has been made both before and after Wyman-Gordon; all other courts have rejected it. ${ }^{31}$ For the purpose of this Comment, it will be assumed that enforcement of the Excelsior rule in the district courts is not improper; the only issue discussed is whether the Board's policy was "improperly promulgated" and therefore inappropriate for enforcement.

\section{The Wyman-Gordon Decrsion}

The litigation in Wyman-Gordon àrose from the efforts of two unions to represent employees of the Wyman-Gordon Company. ${ }^{32}$ When the Board's regional director ordered an election and directed the company to furnish an Excelsior list, the company responded with a list of names without addresses. ${ }^{33}$ The unions fared badly in the election, and the regional director set it aside, ordering a new one and again demanding a list of both names and addresses. ${ }^{34}$ When the company refused to comply a second time, the Board issued a subpoena for the list; it brought an action in the United States District Court for the District of Massachusetts seeking enforcement of the subpoena or, alternatively, a mandatory injunction to force production of the list. ${ }^{35}$

The district court ordered enforcement of the subpoena, ${ }^{36}$ but the First Circuit reversed. The majority opinion ${ }^{37}$ noted that in Excelsior, "the Board, to put it bluntly, designed its own rulemaking procedure . . . [and] to the extent the Board was not deciding a case, this is precisely where Congress has instructed it as to the procedure it should adopt." 38 The First Circuit apparently assumed that if the Board was not adjudicating, it must have been rulemaking, and that if the Excelsior requirement was "improperly promulgated" in that proceeding it could not now be enforced in the Wyman-Gordon litigation. ${ }^{39}$

31 Before: see NLRB v. Q-T Shoe Mfg. Co., 279 F. Supp. 1, 5 (D.N.J. 1968); NLRB v. Beech-Nut Life Savers, Inc., 274 F. Supp. 432, 438 (S.D.N.Y. 1967)' After: see Groendyke Transport, Inc. v. Davis, 59 CCH LAB. L. REP. I 13,176 (5th Cir. Jan. 2, 1969) ; British Auto Parts, Inc. v. NLRB, 59 CCH LAB. I. REP. T 13,134 (9th Cir. Dec. 17, 1968); NLRB v. Beech-Nut Life Savers, Inc., 59 CCH LAB. L. REP. $\| 13,105$ (2d Cir. Dec. 3, 1968).

32397 F.2d 394, 395 (1st Cir. 1968).

33 Id. at $395-96$.

34 Id. at 396.

$35 I d$.

$36 I d$.

37 Judge Coffin dissented; he viewed the Excelsior rule as "procedural" and thus issuable without compliance with the notice and publication provisions of 5 U.S.C. $\$ 553$ (Supp. III, 1968). Id. at 398-99. Procedural rules are specifically exempted from $\S 553$. 5 U.S.C. $\$ 553$ (b) (3) (A) (Supp. III, 1968).

38 Id. at 396-97.

39 Id. at $396-98$. 
Wyman-Gordon raises three major issues. ${ }^{40}$ First, is it true that because the "rule" the Board decided upon in Excelsior was not applied to the parties in that case, it was therefore not a valid adjudication of that policy? Second, what is the relevance of the fact that proceedings for "the certification of worker representatives" are specifically exempted from the APA adjudication procedures? ${ }^{41}$ Third, even if the promulgation of the list requirement in Excelsior did not satisfy APA procedure, is such a defect sufficient to prevent the application of the rule to parties in subsequent adjudications or other proceedings that are otherwise proper?

\section{Prospectivity and Adjudication}

As to the parties themselves, it is clear that there was a valid adjudication in Excelsior: the Board decided the case and issued an order to the parties. The question is whether the substantive policy known as the Excelsior rule was adopted through that proceeding. The First Circuit viewed the policy announced in Excelsior as no more resulting from an "adjudication" than if the Board had merely called a press conference to announce the list requirement, or had announced a new back pay policy in the course of the Excelsior decision. However, the differences are obvious: the merits of the proposed list requirement were fully argued by the parties to Excelsior, and detailed

40 Another aspect of the Wyman-Gordon decision is the relevance of the doctrine of harmless error to an "invalid" policy: does it necessarily follow that if a policy is invalidly adopted, a court should not enforce it? Or should some showing of prejudice be required? Such a showing might be compelled by statute, which provides that a court reviewing agency action shall take "due account" of "the rule of prejudicial error." 5 U.S.C. $\$ 706$ (Supp. III, 1968). Cf. United States v. Aarons, 310 F.2d 341 (2d Cir. 1962) (failure of agency to comply with $\$ 552$ publishing requirement does not invalidate rule if there is actual notice to party alleging invalidity); but see Hotch v. United States, 212 F.2d 280 (9th Cir. 1954) (unless prescribed procedures are complied with, "rule has not been legally issued, and consequently it is ineffective").

The court in Wyman-Gordon stated that "to blink at this procedure in this instance because we may approve of the result . . . would be to emasculate the statute." Wyman-Gordon Co. v. NLRB, 397 F.2d 394, $397^{\circ}$ (1st Cir. 1968). But such a possibility is inherent in the doctrine of harmless error. Every time an appellate court affirms a lower court which has erroneously admitted "harmless" evidence, it might be argued that the rules of evidence are being "emasculated." It is arguable that Congress decided to assume such a risk when it adopted 5 U.S.C. $\$ 706$ (Supp. III, 1968 ). The original draft of what has become 5 U.S.C. $\$ 706$ provided that a reviewing court should "hold unlawful and set aside agency action, findings, and conclusions found . . (4) without observance of the procedure required by law resulting in prejudicial error." The Senate Judiciary Committee suggested that the phrase "resulting in prejudicial error" be omitted and that the statute be changed to require only "due observance" of the rule of prejudicial error, "on the ground that the materiality of the error should be tested by the usual rules and that the present statement requiring a showing of prejudicial error may be unjust and unworkable where the failure of the agency to afford procedure is so severe that the party has no opportunity to even present his case." See STAFF of Senate Comm. on THE JUDIciary, 79th Cong., 1st Sess., Report on Administrative Precedure Act (Comm. Print 1945). The error alleged in Wyman-Gordon does not seem to be of the magnitude of that which the legislators feared.

41 See 5 U.S.C. $\$ 554$ (a) (6) (Supp. III, 1968). 
analysis of these points was given by the Board in its opinion. The question, then, is whether the Board's failure to apply the list requirement to the case in which the desirability of such a requirement was litigated (and, indeed, "decided") means that it did not arise from an "ad hoc litigation" within the meaning of Chenery.

The apparent belief of the First Circuit that an agency must apply a new policy to the parties before it for that policy to be the result of adjudication seems to be contradicted by what case law there is on the subject. Like agencies, courts have promulgated detailed and precise rules in adjudication and have applied them prospectively. The constitutionality of prospective overruling by a state court was determined in Great Northern Railway Co. v. Sunburst Oil \& Refining Co., ${ }^{42}$ and that procedure has been used, though not often, by the federal courts and agencies as well. ${ }^{43}$

The Board itself has used the prospective technique before in cases such as Ideal Electric and Manufacturing Co., ${ }^{44}$ where the Board modified its "Woolworth rule" concerning the cutoff date beyond which the Board would not consider objections based upon interference with an election. The Board decided to apply the newly announced policy "only to those cases filed on or after the date of this decision." 45 A similar procedure was followed by the Board in Goodyear Tire \& Rubber $\mathrm{Co}^{48}$ Its authority to do so was specifically upheld in Rockzrell Manufacturing Co. v. NLRB, ${ }^{47}$ where the Court of Appeals for the Seventh Circuit stated:

While Rockwell's individual situation excites our sympathy, we must admit that providing for prospective application of the new rule was neither arbitrary nor capricious. The Board may fix the effective date of its rule changes and apply its standards prospectively. ${ }^{48}$

Thus, the case law tends to support the conclusion that Excelsior was merely an example of prospective adjudication. The APA, however, cannot be read to lead to a definite conclusion one way or the other. On the one hand, the fact that the rule announced was to have only future effect militates toward finding that the process of

42287 U.S. 358 (1932).

43 See Molitor v. Kaneland Community Unit School Dist., 18 I11. 2d 11, 163 N.E. 2d 89 (1959) (state court) ; cf. Alabama-Tennessee Nat. Gas Co. v. FPC, 359 F.2d 318 (5th Cir. 1966) (federal agency); see generally Comment, Prospective Overruling and Retroactive Application in the Federal Conts, 71 YALE L.J. 907, 921-33 (1962).

44134 N.I.R.B. 1275 (1961).

45 Id. at 1278.

46138 N.L.R.B. 453 (1962).

47330 F.2d 795 (7th Cir.), cert. denied, 379 U.S. 890 (1964).

$48 \mathrm{Id}$. at 798. 
formulation was rulemaking - with defects. "Rule" is defined as an "agency statement of general or particular applicability and future effect." 49 The Excelsior rule certainly fits that description. On the other hand, what the NLRB did in Excelsior looks like adjudication. The APA defines adjudication as the "process for the formulation of an order" and order is defined to include the "whole or part of a final disposition, whether affirmative, negative, injunctive, or declaratory in form." ${ }^{50}$ There is no requirement that the rule formulated in adjudicatory proceedings be applied retroactively to the parties. Since the issue was raised in a specific case, and since there was an adversary proceeding, one could easily conclude from a reading of the APA that the proceeding in Excelsior was the usual run-of-the-mill adjudication with a prospective twist. ${ }^{51}$

The proper way for a court to escape from this dilemma is to defer to the judgment of the agency: if the agency claims it performed adjudication and that claim is consistent with the APA, the only question for the court should be whether the agency complied with the APA's procedural requirements for adjudication. The Wyman-Gordon approach of making the determination whether the NLRB followed rulemaking or adjudication turn on whether the rule formulated in the case was applied prospectively or retroactively may lead to undesirable consequences. One possible result of the Wyman-Gordon decision is that in the future the NLRB will conduct full-blown rulemaking proceedings whenever it formulates new rules. This, however, is hardly likely in light of the past practices of the Board. ${ }^{52}$ The probable result of the decision is that the NLRB will continue to formulate new policy in adjudications, but will not honor justifiable reliance on old rules by applying its new policy prospectively. Instead, rules formulated in adjudications will be applied retroactively; to do otherwise would be to run the risk of having the proceeding invalidated on the ground that rulemaking took place without meeting the APA requirements. Thus, Wyman-Gordon would introduce precisely the

495 U.S.C. $\$ 551$ (4) (Supp. III, 1968), reproduced in note 1 supra.

$50 I d . \S 551(6),(7)$, reproduced in note 1 supra.

51 In British Auto Parts, Inc. v. NLRB, 59 CCH LAB. L. Rep. $\pi 13,134$ at 23,050

(9th Cir. Dec. 17, 1968), the court observed that it was

not able to see how the fact that the Board chose not to make the decisional Rule which it laid down [in Excelsior] controlling of its relief in the particular situation could alter the legal aspect or significance of its general adjudicative holding.

In NLRB v. Beech-Nut Life Savers, Inc., $59 \mathrm{CCH}$ LAB. L. REP. $\| 13,105$ at 22,966 (2d Cir. Dec. 3, 1968), the court stated:

If the Excelsior rule had been tacked onto an opinion dealing with completely unrelated facts and issues we would be inclined to agree with the First Circuit. This was not the situation in Excelsior, however. . . . Clearly the rule announced in Excelsior was substantially based on the facts and issues of that case.

52 See Peck, Critique, supra note 5 , at 260-75. 
kind of rigidity in the administrative process that the Supreme Court warned against in the Chenery case. ${ }^{53}$

\section{APA Exemption of Certification Proceedings}

One very puzzling aspect of the $W y$ man-Gordon case is that there was no discussion of the fact that section 5 of the APA, ${ }^{54}$ which provides the procedures to be followed in adjudications, by its terms does not apply "to the extent that there is involved . . . the certification of worker representatives." Excelsior and its progeny would appear to involve the certification of worker representatives: Excelsior itself was an appeal from a regional director's report recommending that a certification of election results be issued. The report of the Senate Committee on the Judiciary is representative of what little legislative history there is concerning this exemption:

. . . the certification of employee representatives such as the Labor Board operations under section 9(c) of the National Labor Relations Act, is included [in the list of exempt proceedings to which the formal procedures of section 5 should not apply] because these determinations rest so largely upon an election or the availability of an election. ${ }^{55}$

At the time the APA was passed, section 9(c) of the National Labor Relations Act provided:

Whenever a question affecting commerce arises concerning the representation of employees, the Board may investigate such controversy and certify to the parties, in writing, the name or names of the representatives that have been designated or selected. In any such investigation, the Board shall provide for an appropriate hearing upon due notice, either in conjunction with a proceeding under section 160 of this title [governing unfair labor practices] or otherwise, and may take a secret ballot of the employees, or utilize any other suitable method to ascertin [sic] such representatives. ${ }^{58}$

The present section 9 (c) ${ }^{57}$ is somewhat more detailed than that in effect when the APA was passed, and conducting an election is

53 Cf. note 5 supra.

545 UU.S.C. \$ 554 (Supp. III, 1968).

55 S. Rep. No. 752, 79 th Cong., 1st Sess. 16 (1945). See Staff of Senate Coarar. on the Judictary, 79th Cong., 1st Sess., Report on Administrative Act 23 (Comm. Print 1945) ("Those who desire the exemption state that such things as intermediate reports, findings and written decisions are unnecessary because of the simplicity of the issues, the great number of cases, and the exceptional need for expedition.") ; H. Rep. No. 1980, 79th Cong., 2d Sess. 27 (1946) ("determinations rest so largely upon an election or the availability of an election").

56 Act of July 5, 1935, ch. 372, §9(c), 49 Stat. 453.

E7 29 U.S.C. $\$ 159$ (c) (1964). 
no longer discretionary with the Board. However, the Board continues to conduct hearings to determine whether to certify the results of the election, as it did before the amendment to 9 (c).$^{58}$ These proceedings are exempt from the more formal adjudication procedures required by the APA and subject only to the constraints of due process, section 9(c) and the Board's regulations. ${ }^{59}$ In fact, the Board has now delegated this entire function to its regional directors, ${ }^{60}$ who resolve these questions in proceedings which do not comply with the APA adjudication procedures. ${ }^{61}$ Since the Board usually does not review these determinations by the regional directors, ${ }^{62}$ the question arises whether the APA exemption applies only at the regional level or also to review proceedings by the Board. It would seem that the exemption applies at all levels: if the Board were governed by the formal APA procedures, it presumably could not validly delegate these proceedings to the regional directors who do not follow them.

In Wyman-Gordon the First Circuit said that the Board was rulemaking in Excelsior, not adjudicating. ${ }^{63}$ The exemption in section 5 of the APA, giving the Board the power to adopt flexible procedures when it adjudicates, does not give the Board power to ignore the APA when it makes rules. Nevertheless, even if it were conceded that a prospective decision does not validly adopt that policy when the formal procedures of the APA apply, such a requirement should not apply to "informal adjudications"-such as Excelsior-which are exempt from the specific procedures of section 5 of the APA and are governed only by the requirements of due process and the Board's regulations. Thus, even if the Board could not adopt prospectively a requirement such as Excelsior in a section 5 adjudication, it should be permitted to do so in a flexible, non-section 5 adjudication.

58 See Continental Oil Co., 58 N.L.R.B. 169, 333 (1944) (before); General Shoe Corp., 77 N.L.R.B. 124 (1948) (after).

59 See 29 C.F.R. \$§ 101.17-101.21 (1968).

60 See id. § 101.21.

B1 See id. It appears, for example that there is no hearing examiner qualified under $\$ 8$ of the APA, 5 U.S.C. $\$ 557$ (Supp. III, 1968). Cf. NLRB v. Union Brothers, Inc., 403 F.2d 883 (4th Cir. 1968) (only case construing the exemption):

The company also challenges the validity of the board's order on the ground that the hearing officer who presided at the post-election hearing did not meet the eligibility requirements of the Administrative Procedure Act. Congress, however, exempted from these requirements proceedings involving decisions resting solely on "inspections, tests, or elections" and proceedings involving "the certification of worker representatives." 5 U.S.C. \$ 554(a)

(3) (6). In view of this the board's rules designating a hearing officer to consider objections and challenges to the election are not inconsistent with the Administrative Procedure Act.

Id. at 888 (footnotes omitted).

62 See note 18 supra.

63 See text accompanying note 38 supra. 


\section{Relevance of a Defect in a Prior Adjudication to a Subsequent Adjudication}

Even if the list requirement was not "adjudicated" in Excelsior Underwear, Inc., it does not necessarily follow that the Board cannot now set aside elections for failure of an employer to supply a list of employee names and addresses: what was not done in Excelsior was done the first time the Board did set aside an election on that ground. Similarly, to the extent that one agrees that a district court may force compliance with Board "election policy," the list requirement-once validly applied to any party-would appear to be a properly promulgated policy appropriate for enforcement. The question, then, is whether at any time prior to the district court action in Wyman-Gordon the Board validly set aside an election for failure to supply employee names and addresses.

The First Circuit did not think the Board forever barred from requiring an employer to furnish a list of employee names and addresses to the union. It may have expected the Board, after the decision in Wyman-Gordon, to conduct a rulemaking proceeding and readopt the rule. However, since the court indicated no objection to the adoption of such a "rule" by adjudication, a subsequent valid adjudication, in which the policy was applied to the parties, should also operate to resurrect the rule. But why should a post-Wyman-Gordon adjudication be necessary? Logically, any post-Excelsior adjudication which complied with the First Circuit's view of the APA should suffice.

The situation is clouded somewhat by the fact that the Board itself does not normally conduct hearings on whether to set an election aside. The regional directors normally handle these matters, with the Board itself granting hearings only on issues of great moment-as in $E x$ celsior. ${ }^{64}$ However, in British Auto Parts, Inc., ${ }^{65}$ decided after Excelsior and before Wyman-Gordon, the Board did conduct a hearing and set aside an election for failure to supply a list of names and addresses. The employer had not furnished an Excelsior list but had instead sent each employee an envelope addressed to the regional director for use by the employee in providing his name and address. Hence, prior to Wyman-Gordon there was a Board adjudication applying the Excelsior rule. That decision was apparently a valid adjudication of the issue and should have cured any defect in the Excelsior adjudication. ${ }^{68}$

64 See note 18 sipra.

65160 N.L.R.B. 239 (1966), enforced, 59 CCH LAB. L. REp. If 13,134 (9th Cir. Dec. 17, 1968).

66 The Board was presented with an alternative to the requirement decided upon in Excelsior, but it refused to deviate. This was a Board ruling that the Excelsior list requirement was to be followed in all cases, and a specific reaffirmation of its Excelsior "holding." Such a readoption procedure would seem sufficient to comply with the APA "adjudication" provision, 5 U.S.C. \$554 (Supp. III, 1968), which 
Under such a view, an ineffective attempt at adjudication in Excelsior would be treated the same as a situation in which an agency called a rulemaking hearing to formulate policy on a certain issue and then disbanded it without complying with all the APA procedures. If the agency then decided to adjudicate a case raising that issue, such adjudication should be upheld so long as the APA "adjudication" procedures were then complied with; past ineffective action should be irrelevant.

\section{Conclusion}

Perhaps the First Circuit's holding can be interpreted as an expression of dissatisfaction with the prevailing rule of law that the choice of rulemaking or adjudication lies in the discretion of the administrative agency. Wyman-Gordon could be read as saying, "We accept Chenery, as we must, but will go not one inch farther." But the "inch" here is no more than a millimeter-certainly within the rationale of Chenery. Congress has given the agencies discretion in this area, and it is not for the courts to substitute their judgment unless the agency action is arbitrary.

requires that the agency "give all interested parties opportunity for . . . the submission and consideration of facts, arguments . . . when time, the nature of the proceeding, and the public interest permit." Since "the nature of the proceeding" was one to reaffirm a rule the merits of which had already been fully argued, it would seem that the most perfunctory of hearings would suffice-as perfunctory as any postWyman-Gordon "resurrection" hearing presumably would be. 